DOI: $\underline{\text { https://doi.org/10.31933/jemsi.v2i4 }}$

Received: 29 Maret 2021, Revised: 6 April 2021, Publish: 11 Mei 2021

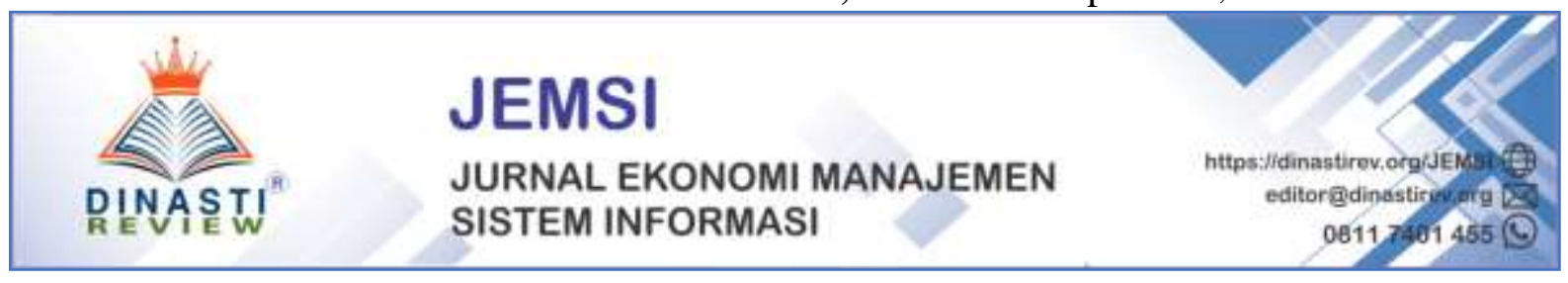

\title{
KINERJA PERUSAHAAN DAN BI RATE TERHADAP RETURN SAHAM BANK BUMN
}

\author{
Laynita Sari ${ }^{1}$, Hilda Mary $^{2}$, Elfiswandi Elfiswandi ${ }^{3}$, Zefriyenni Zefriyenni ${ }^{4}$, Lusiana \\ Lusiana $^{5}$ \\ ${ }^{1)}$ STIE KBP Padang, laynitasari@akbpstie.ac.id \\ 2,3,4) UPI YPTK Padang, hildamary@upiyptk.ac.id
}

\section{Korespondensi Penulis: laynitasari@akbpstie.ac.id}

\begin{abstract}
Abstrak: Penelitian ini bertujuan untuk mengetahui apakah rasio kinerja keuangan dan bunga bank berpengaruh terhadap return saham. Penelitian ini dilakukan pada tahun 2014-2019 pada Bank Badan Usaha Milik Negara yaitu Bank Rakyat Indonesia, Bank Negara Indonesia, Bank Mandiri dan Bank Tabungan Negara. Hasil penelitian menunjukan bahwa Capital Adequacy Ratio dan suku bunga berpengaruh negatif signifikan terhadap return saham. Hal ini menunjukan bahwa ketika Bank Badan Usaha Milik Negara memiliki suku bunga deposito yang tinggi, maka masyarakat/insvestor akan tertarik untuk mendepositokan uangnya daripada berinvestasi di saham. Sehingga Bunga naik mengakibatkan return saham turun. Rasio Net Interest Margin, Loan to Deposit Ratio, Biaya Operasional Pendapatan Operasional berpengaruh tidak signifikan terhadap return saham Bank Badan Usaha Milik Negara. Ketika dilakukan uji simultan diperoleh hasil bahwa Net Interest Margin, Loan to Deposit Ratio, Biaya Operasional Pendapatan Operasional dan Suku Bunga berpengaruh terhadap return saham.
\end{abstract}

Kata Kunci: Kinerja Perusahaan, Bank BUMN, Return Saham.

\section{PENDAHULUAN}

Dalam mendukung berkembangnya suatu negara, roda perekonomian pada dunia bisnis sangat berperan penting bagi masyarakat, pemerintah dan para pengusaha serta investor. Pasar modal merupakan sumber modal atau pendanaan yang mendukung program bisnis ekonomi yang tujuannya memenuhi kebutuhan bagi perorangan, pemerintah, investor dan perusahaan. Bank berperan sebagai system pembayaran, pengendalian inflasi, otoritas moneter, menstabilkan dalam perekonomian Indonesia. Bank BUMN (Badan Usaha Milik Negara) merupakan Bank milik pemerintah dimana mendapat kepercayaan yang lebih oleh masyarakat karena merupakan Bank milik Pemerintah.

Return saham merupakan salah satu daya tarik bagi investor untuk menanamkan modalnya dalam bentuk saham, dimana return dapat memberikan keuntungan yang cukup besar, namun kadang juga mampu memberikan kepuasan tersendiri. Investor harus 
mempertimbangkan faktor teknikal dan faktor fundamental dalam pengambilan keputusan investasinya. Informasi yang bersifat fundamental diperoleh dari kondisi intern perusahaan dan informasi teknikal diperoleh dari luar perusahaan, seperti ekonomi, politik, financial dan faktor lainnya. Pada tahun 2014-2019 terjadi fenomena fluktuasi return saham pada bank BUMN dan menjadi topik masalah bagi para pengusaha, pemegang saham dan calon investor. Fenomena fluktuasi return saha Bank BUMN dari tahun 2014-2019 dapat kita lihat pada tabel dibawah:

Tabel 1 Fluktuasi return saham Bank BUMN Tahun 2014-2019

\begin{tabular}{cccccc}
\hline Tahun & BNI & BRI & BMRI & BBTN & Rata-Rata \\
\hline 2014 & $-0,02$ & 0,00 & 0,01 & 0,06 & 0,01 \\
2015 & 0,00 & 0,02 & 0,04 & 0,01 & 0,02 \\
2016 & 0,05 & 0,06 & 0,10 & 0,06 & 0,07 \\
2017 & 0,20 & 0,10 & 0,07 & 0,09 & 0,12 \\
2018 & 0,01 & $-0,01$ & $-0,03$ & $-0,09$ & $-0,03$ \\
2019 & 0,04 & 0,05 & 0,08 & $-0,02$ & 0,04 \\
\hline
\end{tabular}

Sumber data: dunia investasi

Dari tabel 1 diatas dapat kita lihat bahwa rata-rata return saham Bank BUMN dari tahun 2014-2019 berfluktuasi, dimana tahun 2014 return saham Bank BUMN sebesar 0,01 kemudian ditahun 2015 return saham naik sebesar 0,01 dari tahun 2014 sehingga mmenjadi 0,02, kemudian ditahun 2016 naik sebesar 0,05 dari tahun 2015 sehingga menjadi 0,07, kemudian ditahun 2017 naik sebesar 0,05 dari tahun 2016 sehingga menjadi 0,12, kemudian ditahun 2018 turun sebesar 0,15 dari tahun 2017 sehingga menjadi -0,03, kemudian ditahun 2019 naik sebesar 0,07 dari tahun 2018 sehingga menjadi 0,04.

Return saham akan mempengaruhi perkembangan bisnis bagi perusahaan tersebut apabila tidak ada pengembalian berupa keuntungan maka nilai perusahaan terhadap profitabilitasnya turun sehingga akan terancam perusahaan tersebut akan turun reputasinya yang akan menyebabkan hilangnya kepercayaan bagi para investor yang akan menanamkan modalnya.

Sebelum memutuskan untuk berinvestasi terlebih dahulu investor menilai kinerja perusahaan tersebut. Pengukuran kinerja dapat dilakukan menggunakan rasio keuangan. Analisa rasio keuangan merupakan instrumen analisa perusahaan yang ditujukan untuk menunjukkan perubahan dalam kondisi keuangan perusahaan yang bersangkutan. Dengan analisa rasio keuangan ini dapat diketahui kekuatan dan kelemahan perusahaan di bidang keuangan. Investor tentu akan memperhitungkan dan menilai kinerja keuangan yang terdiri dari rasio-rasio keuangan dalam menjatuhkan pilahannya terhadap suatu saham. Pengaruh Kinerja Keuangan dan...-Setiyono, Erik

Penelitiann sebelumnya tentang pengaruh kinerja keuangan pernah dilakukan oleh (Riyadi, 2014) meneliti pegaruh kinerja keuangan, BI Rate, Earing per Share terhadap harga saham Bank BUMN tahun 2008-2013. Hasil penelitiannya menunjukkan bahwa raio LDR, NIM dan BI Rate berpengaruh positif tidak signifikan terhadap harga saham. Sementara itu rasio CAR dan EPS berpengaruh positif dan signifikan.

Penelitian sebelumnya terhadap return saham terdapat inkonsistensi hasil penelitian. Rasio Net Interest Margin terhadap return saham diteliti oleh (Kurniadi, 2012) menjelaskan bahwa Net Interest Margin (NIM) berpengaruh positif dan signifikan terhadap return saham. sehingga semakin besar Net Interest Margin (NIM) menunjukkan semakin efektif bank dalam 
penempatan aktiva perusahaan dalam bentuk kredit, sehingga return saham bank meningkat. Atau dengan kata lain, semakin besar Net Interest Margin (NIM) suatu bank maka semakin besar juga return saham yang diperoleh bank tersebut, yang berarti kinerja keuangan bank semakin membaik dan meningkat. Sementara itu penelitian yang dilakukan (Devitra, 2017) NIMmempengaruhi harga saham bank secara negatif dan signifikan. Artinya, semakintinggi rasio NIM bisa menyebabkan harga saham bank akan mengalami penurunan. Penelitan yang dilakukan pada objek Bank BUMN juga pernah dilakukan oleh (Sari, Limakrisna, Septiano, 2020) yang menguji apakah rasio Net Interest Margin berpengaruh terhdap kinerja Bank BUMN, hasil penelitiannya menjelaskan bahwa rasio NIM berpengaruh positif signifikan terhadap kinerja Bank BUMN. Hal ini menjelaskan bahwa semakin tinggi nilai rasio NIM maka kinerja Bank BUMN juga semakin baik.

Penelitian sebelumnya tentang pegaruh suku bunga terhadap return saham juga terdapat inkonsistensi terhadap hasil penelitian. Penelitian yang dilakukan oleh (Suriyani, Sudhiartha, 2018) menyatakan bahwa tingkat suku bunga berpengaruh positif dan tidak signifikan terhadap return saham. Sementara itu penelitian yang dilakukan oleh (Faoriko, 2013) menyatakan bahwa suku bunga berpengaruh negatif dan signifikan terhadap Return Saham, penelitian ini dilakukan pada perusahaan manufaktur.

Penelitian sebelumnya tentang pengaruh Biaya Operasional Pendapatan Operasional terhadap return saham juga terdapat inkosistensi terhadap hasil penelitian. Penelitian yang dilakukan oleh (Praditasari, 2012) menunjukkan bahwa Biaya Operasional pada Pendapatan Operasional tidak berpengaruh terhadap Return saham pada perusahaan perbankan. Sementara itu penelitian yang dilakukan oleh (wijaya et al, 2012) menunjukkan adanya pengaruh yang signifikan antara BOPO terhadap return saham.

Penelitian sebelumnya tentang Capital Adequacy Ratio (CAR) terdapat hasil penelitian yang inkonsisteni. Penelitian yang diakukan oleh (Marviana, 2009) dan (Asna, 2006) berkesimpulan bahwa Capital Adequacy Ratio (CAR) mempunyai hubungan yang negatif dan tidak berpengaruh terhadap return saham. Sementara itu penelitian yang dilakukan oleh (Ayem dan Wahyuni, 2017) menunjukkan bahwa Capital Adequacy Ratio (CAR) memiliki nilai koefisien yang positif yaitu sebesar (+) 0,944. Nilai koefisien positif menunjukkan bahwa CARterhadap returnsahamberpengaruh positif.

Pada penelitian ini menggunakan return saham sebagai variabel dependen, Kinerja Perusahaan dan BI Rate sebagai variabel independen. Fluktuasi dari return saham, Kinerja Perusahaan dan suku bunga hal yang menarik untuk dijadikan penelitian karena menjadi topik masalah yang dapat memberikan informasi kepada stockholder, investor, pemerintah dan masyarakat dalam menentukan pilihan investasi yang baik di Bank.

\section{KAJIAN PUSTAKA}

\section{Bank Pemerintah / Bank Badan Usaha Milik Negara}

Bank Pemerintah diatur dalam Undang-undang No. 19 Tahun 2003 tentang Badan Usaha Milik Negara (selanjutnya disebut dengan UU BUMN). Undang-undang ini memberikan pengertian dari BUMN itu sendiri. Pada Pasal 1 angka 1 UU BUMN menyatakan bahwa BUMN adalah badan usaha yang seluruh atau sebagian besar modalnya dimiliki oleh negara melalui penyertaan langsung yang berasal dari kekayaan negara yang dipisahkan. 
Di Indonesia ada empat bank BUMN yang masuk dalam kategori Himpunan Bankbank Milik Negara atau Himbara. Empat bank itu diantaranya Bank Rakyat Indonesia (BRI), Bank Mandiri, Bank Negara Indonesia (BNI) dan Bank Tabungan Negara (BTN).

\section{Return Saham}

Return merupakan hasil yang diperoleh dari investasi. Return dapat berupa return realisasi yang sudah terjadi atau return ekspektasi yang belum terjadi tetapi yang diharapkan akan terjadi di masa mendatang (Jogiyanto, 2003). Return realisasi (realized return) merupakan return yang telah terjadi. Return realisasi dihitung berdasarkan data histori. Return realisasi penting karena digunakan sebagai salah satu pengukur kinerja dari perusahaan. Return histori ini juga berguna sebagai dasar penentuan return ekspektasi (expected return) dan resiko di masa mendatang.

Return ekspektasi (expected return) adalah return yang diharapkan akan diperoleh oleh investor di masa mendatang. Berbeda dengan return realisasi yang sifatnya sudah terjadi, return ekspektasi sifatnya belum terjadi. Return yang digunakan dalam penelitian ini adalah return realisasi (realized return) yang merupakan capital gain/capital loss yaitu selisih antara harga saham periode saat ini $(\mathrm{Pt})$ dengan harga saham pada periode sebelumnya $(\mathrm{Pt}-1)$. Apabila harga saham sekarang (Pt) lebih tinggi dari harga saham periode lalu (Pt-1) maka terjadi keuntungan modal (capital gain), dan sebaliknya apabila harga saham sekarang $(\mathrm{Pt})$ lebih rendah dari harga saham periode lalu (Pt-1) maka terjadi kerugian modal (capital loss).

\section{Kinerja Keuangan}

Kinerja keuangan perusahaan merupakan salah satu faktor yang dilihat oleh calon investor untuk menentukan investasi saham. Kinerja keuangan perusahaan dapat menjadi petunjuk arah naik turunnya harga saham suatu perusahaan. Baik dan buruknya suatu perusahaan dapat digambarkan melalui kinerja keuangan suatu perusahaan. Hal ini dapat diketahui dengan menganalisis menggunakan alat-alat analisis keuangan untuk mengetahui baik buruknya kondisi keuangan dan prestasi keuangan sebuah perusahaan dalam waktu tertentu (Wibowo, 2014). Suatu keharusan bagi sebuah perusahaan menjaga dan meningkatkan kinerja keuangan, agar saham tersebut tetap diminati oleh investor.

Kinerja keuangan perusahaan dapat dicerminkan melalui laporan keuangan yang diterbitkan perusahaan tersebut. Selain itu analisis terhadap informasi laporan keuangan dapat digunakan sebagai dasar pertimbangan oleh investor untuk mengetahui perbandingan antara nilai intrinsic saham perusahaan dengan harga pasar saham perusahaan yang bersangkutan, dan atas pertimbangan tersebut investor dapat mengambil keputusan apakah membeli ataukah menjual saham perusahaan yang bersangkutan. Fungsi informasi keuangan adalah sebagai sarana informasi, alat pertanggungjawaban manajemen kepada pemilik perusahaan, bahan pertimbangan dalam pengambilan keputusan, dan penggambaran terhadap indikator keberhasilan perusahaan. Informasi keuangan tersebut akan digunakan sebagai tolak ukur dan pedoman bagi investor dalam melakukan transaksi jual-beli saham suatu perusahaan. Analisa rasio keuangan dapat digunakan sebagai alat pengukur kinerja kuangan.

Analisis rasio keuangan merupakan dasar untuk menilai dan menganalisis prestasi operasi perusahaan. Rasio keuangan, berisi data tentang posisi perusahaan pada suatu titik operasi perusahaan masa lalu. Rasio-rasio keuangan digunakan untuk menghindari permasalahan dalam membandingkan perusahaan-perusahaan yang berbeda dari sisi ukuran (Ross, 2003). Dalam penelitian ini kinerja keuangan perusahaan diukur dengan menggunakan Rentabilitas diwakili oleh rasio NIM, Likuiditas diwakili oleh rasio LDR, Solvabilitas diwakili oleh CAR, Efisiensi diwakili oleh rasio BOPO . 


\section{Net Interest Margin}

Net Interest Margin (NIM) adalah perbandingan antara pendapatan bunga bersih terhadap rata-rata aktiva produktif. Rasio ini mengindikasi kemampuan bank menghasilkan pendapatan bunga bersih dengan penempatan aktiva produktif. Semakin besar rasio ini semakin baik kinerja bank dalam menghasilkan pendapatan bunga. Namun harus dipastikan bahwa ini bukan karena biaya intermediasi yang tinggi, asumsinya pendapatan bunga harus ditanamkan kembali untuk memperkuat modal bank (Taswan, 2010).

Menurut SE BI No. 13/24/DPNP tanggal 25 Oktober 2011 standar NIM yang ditetapkan untuk bank-bank di Indonesia adalah minimal 3\%. Maka rumusan untuk menghitung Net Interest Margin (NIM) dapat dirumuskan sebagai berikut:

$$
N I M=\frac{\text { Net Interest Income }}{\text { Average Productive Assets }} \times 100 \%
$$

Penelitian sebelumnya tentang pengaruh Net Interest Margin terhadap return saham diteliti oleh (Kurniadi, 2012) yang melakukan penelitian pada saham perbankan Indonesia, menghasilkan bahhwa Net Interest Margin (NIM) berpengaruh signifikan terhadap return saham. Hasil penelitian yang serupa juga dikemukakan oleh (Fathoni, 2010) yang juga meneliti pada saham perbankan di Indonesia menyatakan Net Interest margin (NIM) mempunyai hubungan yang positif dan berpengaruh signifikan terhadap return saham. Hasil penelitian yang serupa juga dilakukan oleh (Marviana, 2009) yang juga meneliti pada saham perbankan di Indonesia menyatakan Net Interest margin (NIM) mempunyai hubungan yang positif dan berpengaruh signifikan terhadap return saham. Hal ini berarti semakin tinggi nilai Net Interest Margin, maka nilai return saham juga akan naik.

Berdasarkan kajian teoritis dan hasil penelitian terdahulu diatas dapat dilihat bahwa adanya pengaruh signifikan dari Net Interest Margin (X1) terhadap Return Saham (Y). Sehingga ini berarti apabila NIM naik maka akan meningkatkan return saham Bank BUMN. Maka dapat peneliti turunkan hipotesis pertama sebagai berikut :

\section{H1 : NIM berpengaruh positif terhadap retun saham Bank BUMN}

\section{Loan to Deposit Ratio (LDR)}

LDR merupakan rasio yang menggambarkan perbandingan antara kredit yang dikeluarkan oleh sebuah bank dengan total dana pihak ketiga yang dihimpun oleh sebuah bank (Kasmir, 2014). Rasio ini akan menunjukkan tingkat kemampuan bank dalam menyalurkan dana pihak ketiga yang dihimpun oleh bank yang bersangkutan. Berdasarkan ketentuan Bank Indonesia No. 15/7PBI/2013 tanggal 1 Oktober 2013, angka LDR seharusnya berada di sekitar $78 \%$ - 100\%.

$$
L D R=\frac{\text { Kredit }}{\text { Dana Pihak Ketiga }} \times 100 \%
$$

Penelitian sebelumnya tentang pengaruh LDR terhadap return saham diteliti oleh (Saputri, 2019) penelitian yang dilakukan pada saham perbankan di Indonesia, menunjukkan bahwa LDR tidak berpengaruh signifikan terhadap return saham. Hasil penelitian yang serupa juga dilakukan oleh (Zulfa, 2013) penelitian dilakukan pada perusahaan perbankan di Bursa Efek Indonesia menunjukkan bahwa Loan to Deposite Ratio (LDR) tidak berpengaruh signifikan terhadap return saham. Artinya informasi kinerja perusahaan dari segi likuiditas dengan alat ukur LDR tidak mempengaruhi reaksi pasar/ investor. Berdasarkan uraian tersebut, maka dapat dibuat hipotesis sebagai berikut :

\section{H2 : LDR berpengaruh negatif terhadap return saham}




\section{Capital Adequacy Ratio (CAR)}

Capital Adequacy Ratio (CAR) adalah rasio yang memperlihatkan seberapa jauh seluruh aktiva bank yang mengandung risiko (kredit, penyertaan, surat berharga, tagihan pada bank lain) ikut dibiayai dari dana modal sendiri bank, disamping memperoleh dana-dana dari sumber-sumber di luar bank, seperti dana masyarakat, pinjaman (utang), dan lain-lain (Dendawijaya, 2009). Bank Indonesia mewajibkan setiap bank umum menyediakan modal minimum sebesar $8 \%$ dari total aktiva tertimbang menurut risiko (ATMR).

Berdasarkan SE BI No.13/24/DPNP tanggal 25 Oktober 2011, penilaian faktor permodalan (capital) meliputi penilaian terhadap tingkat kecukupan permodalan serta penilaian mengenai pengelolaan permodalan bank. Faktor capital dapat diukur dengan menggunakan Capital Adequacy Ratio (CAR). Rumus perhitungan Capital Adequacy Ratio (CAR) yaitu:

$$
C A R=\frac{\text { Modal }}{\text { Aktiva Tertimbang Menurut Resiko }} \times 100 \%
$$

Penelitian sebelumnya tentang Capital Adequacy Ratio terhadap return saham dilakukan oleh (Ayem dan Wahyuni, 2017) menunjukkan bahwa Capital Adequacy Ratio (CAR) memiliki nilai koefisien yang positif yaitu sebesar (+) 0,944. Nilai koefisien positif menunjukkan bahwa CARterhadap returnsahamberpengaruh positif. Hasil penelitian yang sama juga dilakukan oleh (Patricia, 2021) menunjukkan bahwa Risiko Likuiditas dan Capital berpengaruh positif terhadap Return Saham Perbankandi Indonesia. Hipotesis penelitian adalah apabila Risiko Likuiditas dan Capital mengalami peningkatan maka Return Saham juga mengalami peningkatan. Maka dapat peneliti turunkan hipotesis sebagai berikut:

\section{H3 : CAR berpengaruh positif terhadap return saham}

\section{Biaya Operasional Pendapatan Operasional (BOPO)}

Rasio BOPO merupakan perbandingan antara biaya operasional dan pendapatan operasional (Siamat, 2005). Rasio BOPO menunjukan keefektifan bank dalam melakukan kegiatan operasionalnya. Jika dalam kegiatan operasionalnya perbankan menghasilkan biaya operasional yang lebih besar dibandingkan pendapatan operasionalnya hal itu berarti bank tersebut tidak efisien dalam melakukan kegiatan operasional. Biaya operasional yang besar juga akan mengurangi laba perusahaan hal itu dikarenakan biaya operasional menjadi pengurang laba perusahaan dalam laporan laba-rugi.

Berdasarkan SE BI No.13/24/DPNP tanggal 25 Oktober 2011, Rumus perhitungan Biaya Operasional Pendapatan Operasional (BOPO) yaitu:

$$
\text { BOPO }=\frac{\text { Biaya Operasional }}{\text { Pendapatan Operasional }} \times 100 \%
$$

Penelitian sebelumnya tentang BOPO terhadap return saham diteliti oleh Wijaya, et al (2012) menunjukkan adanya pengaruh yang signifikan antara BOPO terhadap return saham. Penelitian lainnya juga dilakukan oleh (Saputri, 2019) dengan hasil Biaya Operasional terhadap Pendapatan Operasional (BOPO) menunjukan ada pengaruh negatif dan signifikan terhadap return saham pada perusahaan perbankan yang terdaftar di Bursa Efek Indonesia. Berdasarkan kajian teoritis dan hasil penelitian terdahulu diatas dapat dilihat bahwa adanya 
pengaruh signifikan dari Biaya Operasional Pendapatan Operasional (x4) terhadap return saham (y). Hal ini berarti bahwa diasumsikan ada hubungan dan pengaruh negatif yang signifikan antara BOPO dengan return saham. Sehingga ini berarti apabila rasio BOPO yang naik maka akan menurunkan Return Saham Bank BUMN. Maka dapat peneliti turunkan hipotesis sebagai berikut :

\section{H4 : BOPO berpengaruh negatif terhadap return saham}

\section{Bunga Deposito}

Suku bunga merupakan instrumen konvensional untuk mengendalikan atau menekan laju pertumbuhan tingkat inflasi. Suku bunga yang tinggi akan mendorong orang-orang untuk menanamkan dananya di bank daripada menginvestasikannya pada sektor produksi atau sektor industri yang risikonya jauh lebih besar jika dibandingkan dengan menanamkan uang di bank terutama dalam bentuk deposito. (Santoso, 2003) mendefenisikan suku bunga sebagai harga dari penggunaan uang untuk jangka waktu tertentu, atau harga dari penggunaan uang yang dipergunakan pada saat ini dan akan dikembalikan pada suatu saat mendatang. Pengertian tingkat bunga sebagai "harga" ini juga dapat dinyatakan sebagai harga yang harus dibayar apabila terjadi "pertukaran" antara satu rupiah di waktu yang akan datang. Dengan demikian dapat disimpulkan bahwa suku bunga deposito adalah harga yang akan diperoleh dari penggunaan uang untuk jangka waktu tertentu atau harga dari penggunaan uang yang dipergunakan pada saat ini dan akan dikembalikan pada suatu saat mendatang.

Penelitian sebelumnya tentang pengaruh bungan deposito terhadap return saham dilakukan oleh (Faoriko, 2013) menunjukkan bahwa Suku Bunga berpengaruh negatif dan signifikan terhadap Return Saham pada perusahaan manufaktur yang terdaftar di BEI periode 2008-2010. Hasil penelitian yang serupa juga dilakukan oleh ( Riantani dan Tambunan, 2013) menunjukkan bahwa suku bunga SBI memiliki nilai koefisien regresi negatif, hal ini mengandung arti kenaikan suku bunga SBI akan menurunkan return saham.

Berdasarkan kajian teoritis dan hasil penelitian terdahulu diatas dapat dilihat bahwa adanya pengaruh negatif dari Bunga Deposito (X2) terhadap return saham (Z). Sehingga ini berarti apabila rasio Bunga Depoito yang naik maka return saham Bank BUMN akan turun. Maka dapat peneliti turunkan hipotesis sebagai berikut :

\section{H5 : Bunga berpengaruh negatif terhadap return saham}

Penelitian ini juga akan meneliti pengaruh NIM, LDR, CAR, BOPO, Suku Bunga Deposito secara bersama-sama terhadap return saham Bank BUMN. Sehingga dapat peneliti turunkan hipotesis sebagai berikut:

H6 : NIM, LDR, CAR, BOPO dan Bunga Deposito berpengaruh secara simultan terhadap return saham

\section{METODE PENELITIAN}

\section{Lokasi Penelitian}

Penelitian ini dilakukan pada Bank BUMN melalui data laporan keuangan periode tahun 2014-2019. Melalui laporan keuangan yang dimiliki Bank BUMN, peneliti mengolah data tersebut sesuai dengan variabel yang digunakan dalam penelitian, baik untuk variabel independen, variabel mediasi, maupun variabel dependen. Dengan demikian data yang di olah oleh peneliti adalah data kuantitatif. Laporan keuangan yang digunakan diperoleh dari masingmasing website resmi bank BRI, Bank BNI, Bank Mandiri, dan Bank BTN. Sementara, data saham diperoleh dari dunia investasi.com. 
Penelitian kuantitatif memasukkan pustaka yang relatif banyak untuk memberi arah terhadap pertanyaan-pertanyaan penelitian atau hipotesis. Dalam merencanakan penelitian kuantitatif, kajian pustaka seringkali digunakan untuk mengantarkan suatu masalah dalam pendahuluan, (Ali \& Limakrisna, 2013).

\section{Rancangan Penelitian}

Penelitian yang dilakukan ini ingin mengetahui bagaimana pengaruh variabel independen yaitu NIM, LDR, CAR, BOPO dan Bunga Deposito terhadap variabel dependen yaitu return saham Bank Pemerintah. Penelitian ini menggunakan data berupa laporan keuangan milik Bank Pemerintah pada periode tahun 2014-2019. Data laporan keuangan ini diperoleh dari masing-masing website resmi bank BRI, Bank BNI, Bank Mandiri, dan Bank BTN. Sementara itu, data saham diperoleh dari situs duniainvestasi.com.

\section{Metode Pengumpulan Data}

Metode pengumpulan data dalam penelitian ini yaitu dengan mengumpulkan data dari laporan keuangan dan data saham milik Bank Pemerintah dari periode 2014 sampai 2019. Data laporan keuangan ini diperoleh dari masing-masing website resmi bank BRI, Bank BNI, Bank Mandiri, dan Bank BTN serta situs duniainvestasi.com.

\section{Jenis dan Sumber Data}

Jenis data yang digunakan dalam penelitian ini adalah data sekunder yaitu data yang sudah berupa laporan, sudah tercatat dan dapat dipercaya kebenarannya. Sedangkan sumber data dalam penelitian ini berasal dari situs resmi Bank Pemerintah yang berupa laporan keuangan semesteran milik Bank BRI, Bank BNI, Bank Mandiri dan Bank BTN serta situs duniainvestasi.com dari tahun 2014-2019.

Analisis Data

Metode analisis data yang digunakan dalam penelitian ini adalah regresi linier berganda (multiple regression analysis), analisa regresi ini digunakan untuk mempelajari hubungan antara satu variabel terikat (dependen variable) terhadap satu atau lebih variabel bebas (independen variable dengan alat bantu SPSS (Statistical Product and Service Solution) yang berguna untuk membantu pengujian secara statistik.

\section{HASIL DAN PEMBAHASAN}

\begin{tabular}{|c|c|c|c|c|c|c|}
\hline \multicolumn{7}{|c|}{ Tabel 2. Hasil Pengolahan Data } \\
\hline & \multirow{2}{*}{ Model } & \multicolumn{2}{|c|}{$\begin{array}{l}\text { Unstandardized } \\
\text { Coefficients }\end{array}$} & \multirow{2}{*}{$\begin{array}{c}\text { Standardized } \\
\text { Coefficients } \\
\text { Beta }\end{array}$} & \multirow[b]{2}{*}{$t$} & \multirow[b]{2}{*}{ Sig. } \\
\hline & & B & $\begin{array}{l}\text { Std. } \\
\text { Error }\end{array}$ & & & \\
\hline \multirow[t]{6}{*}{1} & (Constant) & 1,107 & 0,302 & & 3,661 & 0,002 \\
\hline & LDR & $-0,001$ & 0,002 & $-0,168$ & $-0,519$ & 0,610 \\
\hline & CAR & $-0,022$ & 0,008 & $-0,827$ & $-2,571$ & 0,019 \\
\hline & BOPO & $-0,001$ & 0,002 & $-0,118$ & $-0,383$ & 0,706 \\
\hline & BUNGA DEPOSITO & $-0,093$ & 0,022 & $-1,205$ & $-4,324$ & 0,000 \\
\hline & NIM & 0,021 & 0,013 & 0,478 & 1,546 & 0,139 \\
\hline
\end{tabular}

Hasil pengujian masing-masing varibel independen terhadap variabel dependennya dapat dianalisis sebagai berikut:

\section{Variabel Net Interest Margin terhadap variabel return saham}


H1 : NIM berpengaruh positif terhadap retun saham Bank BUMN

Hasil pengujian pengaruh NIM terhadap return saham diperoleh nilai t signifikansi sebesar 0,139. Nilai signifikansi lebih besar dari 0,05 menunjukan bahwa NIM berpengaruh tidak signifikan terhadap return saham. Koefisien regresi NIM bernilai positif 0,021 . Hal ini berarti terdapat pengaruh positif dan tidak signifikan rasio rentabilitas yang diwakili oleh NIM (Net Interest Margin) terhadap Return Saham. Dari analisis yang telah dilakukan, diketahui variabel NIM (Net Interest Margin) tidak berpengaruh signifikan secara parsial terhadap return saham. Hal ini berarti Hipotesis 1diterima.

2. Variabel Loan to Deposit Ratio terhadap variabel return saham

H2 : LDR berpengaruh negatif terhadap return saham

Hasil pengujian pengaruh LDR terhadap return saham diperoleh nilai t signifikansi sebesar 0,610. Nilai signifikansi lebih besar dari 0,05 menunjukan bahwa LDR tidak berpengaruh signifikan terhadap return saham. Koefisien regresi LDR bernilai negatif $-0,001$. Hal ini berarti terdapat pengaruh negatif dan tidak signifikan rasio likuiditas yang diwakili oleh LDR (Loan to Deposit Ratio) terhadap Return Saham. Dari analisis yang telah dilakukan, diketahui variabel LDR (Loan to Deposit Ratio) tidak berpengaruh signifikan secara parsial terhadap return saham. Hal ini berarti Hipotesis 2 diterima.

\section{Variabel Capital Adequacy Ratio terhadap variabel return saham}

H3 : CAR berpengaruh positif terhadap return saham

Hasil pengujian pengaruh kompetensi terhadap kinerja diperoleh nilai t signifikansi sebesar 0,019. Nilai signifikannya kecil dari 0,05 berarti bahwa CAR berpengaruh secara signifikan terhadap return saham. Koefisien regresi CAR bernilai negatif $-0,022$. Hal ini berarti terdapat pengaruh negatif dan signifikan rasio solvabilitas yang diwakili oleh CAR (Capital Adequacy Ratio) terhadap Return Saham. Dari analisis yang telah dilakukan, diketahui variabel CAR (Capital Adequacy Ratio) berpengaruh signifikan secara parsial terhadap return saham. Hal ini berarti Hipotesis 3 ditolak.

4. Variabel Biaya Operasional Pendapatan Operasional terhadap variabel return saham

$\mathrm{H} 4$ : BOPO berpengaruh negatif terhadap return saham

Hasil pengujian pengaruh BOPO terhadap return saham diperoleh nilai $\mathrm{t}$ signifikansi sebesar 0,706. Nilai signifikansi lebih besar dari 0,05 menunjukan bahwa BOPO berpengaruh signifikan terhadap return saham. Koefisien regresi BOPO bernilai negatif 0,001. Hal ini berarti terdapat pengaruh negatif dan tidak signifikan rasio efisiensi yang diwakili oleh BOPO (Biaya Operasional Pendpatan Operasional) terhadap Return Saham. Dari analisis yang telah dilakukan, diketahui variabel BOPO (Biaya Operasional Pendpatan Operasional) berpengaruh tidak signifikan secara parsial terhadap return saham. Hal ini berarti Hipotesis 4 diterima.

\section{Variabel Bunga terhadap variabel return saham}

H5 : Bunga berpengaruh negatif terhadap return saham

Hasil pengujian pengaruh bunga terhadap retun saham diperoleh nilai $t$ signifikansi sebesar 0,000. Nilai signifikansi lebih kecil dari 0,05 menunjukan bahwa bunga berpengaruh signifikan terhadap return saham. Koefisien regresi bunga bernilai negatif -0,093. Hal ini berarti terdapat pengaruh negatif dan signifikan rasio bunga terhadap Return Saham. Dari analisis yang telah dilakukan, diketahui variabel bunga berpengaruh signifikan secara parsial terhadap return saham. Hal ini berarti Hipotesis 5 diterima. 


\begin{tabular}{|c|c|c|c|c|c|}
\hline \multicolumn{6}{|c|}{ Tabel 3. Hasil Uji Simultan } \\
\hline Model & $\begin{array}{c}\text { Sum of } \\
\text { Squares }\end{array}$ & df & $\begin{array}{c}\text { Mean } \\
\text { Square }\end{array}$ & F & Sig. \\
\hline $1 \quad \begin{array}{c}\text { Regressi } \\
\text { on } \\
\text { Residual } \\
\text { Total }\end{array}$ & 0,045 & 5 & 0,009 & 5,135 &, $004^{\text {b }}$ \\
\hline & 0,032 & 18 & 0,002 & & \\
\hline & 0,077 & 23 & & & \\
\hline $\begin{array}{l}\text { a. Dependent Variable: RETURN SAHHAM } \\
\text { b. Predictors: (Constant), NIM, BUNGA DEPOSITO, BOPO, CAR, LDR }\end{array}$ \\
\hline
\end{tabular}

\section{Variabel NIM, LDR, CAR, BOPO, Bunga bersama-sama terhadap return saham}

H6 : NIM, LDR, CAR, BOPO dan Bunga Deposito berpengaruh secara simultan terhadap return saham

Hasil pengujian pengaruh secara simultan NIM, LDR, CAR, BOPO, dan Bunga terhadap retun saham diperoleh nilai signifikansi sebesar 0,000. Nilai signifikansi lebih kecil dari 0,05 menunjukan bahwa NIM, LDR, CAR, BOPO, dan Bunga secara bersama-sama berpengaruh signifikan terhadap return saham. Hal ini berarti Hipotesis 6 diterima

\section{KESIMPULAN DAN SARAN}

\section{Kesimpulan}

NIM berpengaruh positif tidak signifikan terhadap return saham Bank BUMN. Hal ini menjelaskan bahwa apabila Bank BUMN memperoleh laba bersih yang naik / turun tidak akan mempengaruhi investor dalam menginvestasikan sahamnya, dan tidak berpengaruh kepada nilai return saham.

LDR berpengaruh negatif tidak signifikan terhadap return saham Bank BUMN. Hal ini menjelaskan bahwa apabila Bank BUMN mengalami kenaikan/penurunan nilai rasio LDR tidak akan mempengaruhi investor dalam menginvestasikan sahamnya, dan tidak berpengaruh kepada nilai return saham.

CAR berpengaruh negatif dan signifikan terhadap return saham Bank BUMN. Hal ini menjelaskan bahwa apabila CAR Bank BUMN tinggi, maka return sahamnya akan turun. Hal ini bisa saja karena pandangan masyarakat terhadap Bank tersebut memiliki CAR yang tinggi, maka masyarakat lebih tertarik untuk mendepositokan uangnya di Bank BUMN.

BOPO berpengaruh negatif tidak signnifikan terhadap return saham Bank BUMN. Hal ini menjelaskan bahwa apabila Bank BUMN mengalami kenaikan/penurunan nilai rasio BOPO tidak akan mempengaruhi investor dalam menginvestasikan sahamnya, dan tidak berpengaruh kepada nilai return saham.

Bunga berpengaruh negatif dan signifikan terhadap return saham Bank BUMN. Hal ini menjelaskan bahwa apabila Bunga Deposito Bank BUMN tinggi, maka return sahamnya akan turun. Hal ini karena masyarakat/investor lebih tertarik untuk mendepositokan uangnya di Bank BUMN daripada berinvestasi di saham.

NIM, LDR, CAR, BOPO dan Bunga Deposito secara simultan berpengaruh terhadap return saham.

\section{Saran}


Peneliti selanjutnya dapat menggunakan rasio lainnya dan dpat meneliti pada objek lainnya dan Peneliti selanjutnya dapat meneliti menggunakan tahun yang lebih lama.

\section{DAFTAR RUJUKAN}

AlexanderWongso, R. (2012). Pengaruh Rasio Keuangan Terhadap Return Saham Pada Bank Mandiri Makasar. In: Skripsi: Universitas Hasanuddin.

Ali, H., \& Limakrisna, N. J. D. Y. (2013). Metodologi Penelitian (Petunjuk Praktis untuk Pemecahan Masalah Bisnis, Penyusunan Skripsi, Tesis, dan Disertasi).

Asna, A., \& Graha, A. N. J. J. E. M. (2006). Analisis Pengaruh Rasio Keuangan Terhadap Return Saham Perbankan Yang Terdaftar Di Bursa Efek Jakarta. 2(3), 192-212.

Ayem, S., \& Wahyuni, S. J. J. A. (2017). Pengaruh Loan To Deposit Ratio, Capital Adequacy Ratio, Return On Asset Dannon Perfoming Loan Terhadap Return Saham. 5(1), 71-87.

Brock, P. L., \& Suarez, L. R. J. J. o. d. E. (2000). Understanding the behavior of bank spreads in Latin America. 63(1), 113-134.

Dendawijaya, L. J. G. I. J. S. (2003). Manajemen Perbankan Cetakan Kedua.

Devitra, J. J. J. K. d. P. (2017). Kinerja Keuangan dan Efisiensi Terhadap Return Saham Perbankan di Bursa Efek Indonesia periode 2007-2011. 15(1).

Faoriko, A. J. P. J. E. U. N. Y. (2013). Pengaruh Inflasi, Suku Bunga Dan Nilai Tukar Rupiah, Terhadap Return Saham Di Bursa Efek Indonesia.

Fathoni, H. (2010). Analisis pengaruh faktor fundamental terhadap return saham perbankan (pada perbankan yang terdaftar di Bursa Efek Indonesia tahun 2004-2008).

Gantino, R., \& Maulana, F. J. S. C. A. (2013). Pengaruh Roa, Car, Dan Ldr Terhadap Return Saham Padaperusahaan Perbankan Yang Terdaftar Di Bursa Efek Indonesia Periode 2008-2012. 3(1).

Hartono, J. J. Y. B. (2003). Teori Portofolio dan Analisis Investasi Edisi Kelima.

Hastuti, P. J. S. B. (2011). Analisis Pengaruh Beban Operasional Pendapatan Operasional (BOPO), Non Performing Loan (NPL), Capital Adequacy Ratio (CAR), Dan Loan To Deposit Ratio (LDR) Terhadap Net Interest Margin (NIM)(Studi Kasus PT Bank Muamalat Indonesia Tbk).

Ihsan, R. W. M., \& Solikhin, A. J. J. P. U. J. S. H. (2012). Pengaruh Rasio Camel terhadap Return Saham pada Industri Perbankan di Bursa Efek Indonesia (Studi Kasus pada Perusahaan Industri Perbankan yang Terdaftar di Bursa Efek Indonesia Periode 20072009). 14(1), 43415.

Khaddafi, M., \& Syamni, G. J. J. a. m. (2012). Hubungan rasio camel dengan return saham pada perusahaan perbankan di bursa efek Indonesia. 9(3), 910-918.

Kurniadi, R. J. A. A. J. (2012). Pengaruh CAR, NIM, LDR Terhadap Return Saham Perusahaan Perbankan Indonesia. 1(1).

Kurniasari, W., Wiratno, A., \& Yusuf, M. J. J. o. A. S. (2018). Pengaruh inflasi dan suku bunga terhadap return saham dengan profitabilitas sebagai variabel intervening di perbankan yang terdaftar di Bursa Efek Indonesia tahun 2013-2015. 2(1), 67-90.

Lukman, D. J. J. G. I. (2009). Manajemen Perbankan.

Marviana, R. D. (2009). Pengaruh Faktor Funda-mental Terhadap Return Saham Perusahaan Per-bankan Yang Terdaftar Di Bursa Efek Indonesia. Universitas Sumatera Utara, Medan.

No, S. E. B. I. J. P. P. T. K. b. U. J. B. I. 13/24/DPNP tanggal 25 Oktober 2011.

Patricia, O., Hidayati, S., \& Wahyudi, W. J. K. R. N. E. M. d. A. (2021). Pengaruh Tingkat Kesehatan Bank Terhadap Return Saham Perbankan di Indonesia. 2(1), 464-476.

Praditasari, A., \& Amanah, L. J. J. I. d. R. A. (2017). Pengaruh Rasio Risk-Based Bank Rating Terhadap Return Saham Perusahaan Perbankan. 6(9). 
Riantani, S., \& Tambunan, M. J. S. (2013). Analisis pengaruh variabel makroekonomi dan indeks global terhadap return saham. 3(1).

Santoso, H. B. J. M. E. T. X. (2003). Pengaruh Perbedaan Laju Inflasi dan Suku Bunga Pada Nilai Tukar Rupiah Terhadap Dollar Amerika Dalam Kurun Waktu Januari 2000Desember 2002. 3.

Saputri, R. I. J. J. E. D. (2019). Analisis Pengaruh CAR, NIM, BOPO dan LDR terhadap Return Saham Pada Perusahaan Perbankan Yang Terdaftar Di Bursa Efek Indonesia Periode Tahun 2011 Sampai Dengan Tahun 2015. 1(1), 149-158.

Sari, L., Limakrisna, N., Septiano, R. J. D. I. J. o. E., Finance, \& Accounting. (2020). Determinant Of Government Bank Performance Through Nim As Intervening. 1(4), 619-628.

Siamat, D., Kusumawardhani, P. N., \& Agustin, F. (2005). Manajemen lembaga keuangan: kebijakan moneter dan perbankan: dilengkapi UU no. 10 tahun 1998, UU no. 23 tahun 1999, UU no. 03 tahun 2004: Lembaga Penerbit Fakultas Ekonomi Universitas Indonesia.

Simanjuntak, J. J. J. o. A., \& Innovation, M. (2018). Inflasi Dan Suku Bunga Terhadap Net Interest Margin Pada Bank Konvensional. 2(2), 161-169.

Suriyani, N. K., \& Sudiartha, G. M. (2018). Pengaruh tingkat suku bunga, inflasi dan nilai tukar terhadap return saham di Bursa Efek Indonesia. Udayana University,

Taswan, C., \& Si, M. J. Y. U. S. Y. Y. (2010). Manajemen Perbankan.

William, J. J. J. o. B., \& banking. (2012). Penyaluran Dana Pihak Ketiga dan Suku Bunga Sebagai Variabel Moderasi Terhadap Profitabilitas Bank. 2(1), 60-70.

Zulfa, I. J. J. A. (2013). Pengaruh Rentabilitas, Likuiditas, Kecukupan Modal dan Ukuran Perusahaan Terhadap Return Saham Pada Perusahaan Perbankan yang Listing di Bursa Efek Indonesia. 1(2). 